\title{
On the Dark Side of the "Secular": Is the Religious-Secular Distinction a Binary?
}

\author{
S. N. Balagangadhara \\ Ghent University \\ Research Centre Vergelijkende Cultuurwetenschap \\ Apotheekstraat 5, B-9000 Gent, Belgium \\ balu@ugent.be
}

\begin{abstract}
Recent scholarship claims to have revealed the problematic nature of the religious-secular distinction: (1) the distinction is slippery or fluid; (2) the meanings of the words "religious" and "secular" have changed over multiple historical contexts; (3) the distinction is a binary; (4) it is essentialist in nature. Analyzing these objections, the article shows that it is very difficult to find a clear problem statement. To whom is the religious-secular distinction a problem and why? The distinction was originally made within Christian theology, where it concerned a triad rather than a binary: true religion, false religions, and the secular. The notion of the secular always required the presence of the opposition between truth and falsity in religion, because it was the sphere that remained after true and false religion had been demarcated. In this sense, the secular had a "dark side," namely idolatry or false religion. To a Christian believer, there is no conceptual problem involved in making the religious-secular distinction, because his theology helps him specify what true and false religion are and, as a consequence, what the secular is. However, because of its neutrality in religious matters, the liberal state has tried to reduce the theological triad to a binary opposition between religion and the secular. The inevitable failure of this attempt has created a formless secular sphere that is haunted by its dark side: the notion of false religion.
\end{abstract}

\section{Keywords}

religious and secular, secularization, false religion, idolatry, essentialism

\section{Sins of a Distinction?}

During the last decade, a great deal of attention has been paid to the distinction between the religious and the secular. Out of these discussions, the following consensus has emerged: making this distinction in the study of religion and elsewhere is problematic (Agrama 2010; Asad 2003; Casanova 2006:21-24; Cavanaugh 2009; Fitzgerald 2007a; Fitzgerald 2007b; Fitzgerald 2007c; Starrett 2010). However, there is no equally clear agreement about what exactly the problem is, why it is a problem, and whether there is a solution to this problem. If the literature that contests 
and debates the distinction between the "religious" and the "secular" is examined in search of the problem statement, several types of arguments can be found.

The anthropologist Talal Asad argues that the secular "is neither continuous with the religious that supposedly preceded it (that is, it is not the latest phase of a sacred origin) nor a simple break from it (that is, it is not the opposite, an essence that excludes the sacred)," but takes "the view, as others have done, that the 'religious' and the 'secular' are not essentially fixed categories" (2003:25). Timothy Fitzgerald questions "the assumption that religious practices can be distinguished from nonreligious or secular practices" and points out that this binary is closely related to various other binary oppositions (religion and politics, religion and economics, religion and science), which are fundamental to modern discourses on religion (2007a:6). In spite of the widely noted difficulty in defining these terms, there is the continuing assumption that their referents are intuitively obvious. Yet Fitzgerald argues "that none of these categories has fixed meanings and that they are fundamentally rhetorical and strategic" (2007a:23). In different historical and political contexts, the meaning of the terms "religious" and "secular" has changed and the borders of the religious-secular dichotomy have shifted. Similarly, William Cavanaugh argues "that there is no transhistorical and transcultural essence of religion and that essentialist attempts to separate religious violence from secular violence are incoherent. What counts as religious or secular in any given context is a function of different configurations of power" (2009:3-4). Other authors have similarly criticized the dichotomous essentialism of the sacredsecular divide or pointed to its fluidity and shifting boundaries (Besserman 2006; van Bremen 1995:2-3).

Broadly speaking, four types of arguments about the religious-secular distinction can be summed up, which keep recurring in the literature: (1) the distinction is slippery or fluid; (2) the meanings of the words "religious" and "secular" have changed over multiple historical contexts; (3) the distinction is a binary or dichotomy; (4) it is essentialist in nature and this essentialism is unacceptable. I will begin by briefly examining the nature of these arguments in order to set up the problem.

The first argument points out the fact that there is no hard and fast set of criteria to make the distinction. Even though the reason for this alleged absence will become clear later on in this essay, let me note here that the absence of a set of criteria can never be a good reason to abandon 
making a distinction. If anything, it should propel us in the direction of research that either provides such criteria or shows why it is impossible to do so.

Second, some scholars seem to think the contextual dependency of this distinction is some kind of an impossibility argument: the fact that the meanings of these words have changed over a period of time demonstrates the impossibility of providing context-independent criteria. This argument is too general to "prove" the impossibility of making a particular distinction. After all, it is a fact about all natural languages that meanings of words change over time and additional meanings accrue in different contexts and that, in some cases, the contexts are the only ways of disambiguating the meaning of a word, especially where a single word has several unrelated meanings. From this consideration alone, it does not follow that this distinction faces some specific unsolvable problems. Since it is not possible to make the radical claim that words do not have any meaning outside of the contexts where they occur, the occurrence of this distinction in multiple historical contexts with multiple meanings does not establish the case that, therefore, this distinction makes no sense to us in our context.

The next two arguments are philosophical in nature, but it is not clear what the philosophy in question is or even how it provides arguments against the distinction. The strongest logic that we know (the truth-functional propositional and predicate calculus) works with binary values and neither paraconsistent nor multi-valued logics "disprove" propositional or predicate calculus. Our electrical circuits are binary and so is the best arithmetic we can think of. Consequently, it is unclear why it is "wrong" to work with binaries or dichotomies.

Perhaps, the problem that these scholars wish to identify is not at all about binaries but about a mode of reasoning that logicians identify as a fallacy in informal logic: the mistake in reasoning commonly called the fallacy of the excluded middle (or as a "false dilemma"). Here, the problem is simple: in the case of logical contraries (both of which could be false), one argues for the truth-value of one contrary based on the truth-value of the other. However, the problem here is not that the distinctions are binaries but that they are logical contraries. In the case of two statements that divide the logical space into two exhaustive partitions such that only one of them could be true, no such problem arises. In other words, it is totally unclear whether people have problems with two-valued logics or are making heavy weather by falsely generalizing a specific fallacy as a problem for all reasoning that involves two values. 
As far as the sin of essentialism is concerned, it is not at all obvious what kind of essentialism one is against or even why. The problem with essentialism appears to be this: one freezes the world into static essences and, therefore, one cannot understand the dynamic, changing nature of things. This charge is untrue, but, even if true, consider a counter-question: Would a dynamic "essentialism" be permitted then? After all, Aristotle, the grandfather of one kind of essentialism, and Hegel, the progenitor of another kind of essentialism, speak of dynamic essences. Their theories are predicated upon essences that develop, change, and morph. What is wrong with these kinds of essentialism? Furthermore, the distinction between the secular and the religious is empirical and not metaphysical in nature. Consequently, the charge of essentialism appears misplaced. Of course, one might want to say that it is not misplaced in the sense that scholars transform an empirical distinction into a metaphysical one.

In that case, consider a modern-day logician and philosopher like Saul Kripke (1981). His "essentialism" tries to solve the problem of trans-world identity in possible world semantics. He proposes that proper names be thought of as rigid designators that refer to individual "essences" and suggests that our scientific theories identify "essences" of natural kinds. While, indeed, some philosophers are wary of Kripke's proposal (like, say, David Lewis [2001]; see also Berger 2011), it is not obvious whether the writers in religious studies have Kripkean essentialism in mind, when they speak as though it is a cardinal sin to espouse essentialism.

Of course, a nominalist like William of Ockham might deny the presence of "essences" in the world. But such nominalism is merely one philosophical option among others and not the only one. Further, given the presence of multiple notions of "essentialism" and the absence of any knockdown refutations of any of these philosophical doctrines, one has to do more than cry "wolf" if the stricture against essentialism is to carry bite. That is not the case here.

In short, it is not obvious what the problems are and it is very difficult, if not impossible, to find a clear problem statement. The only consensus is that there is some kind of problem involved in making the distinction between the "religious" and the "secular" and that any such distinction is a binary. What I will now do, therefore, is attempt a clear problem statement beginning with the question: to whom is this distinction a problem and why? 


\section{A Christian Triad}

Most of us know that, as a historical fact, Christianity made a distinction between the religious and the secular or the spiritual and the temporal. It is also widely known, even if one has not studied the history of the use of this distinction in Christianity, that the words "religious" and "secular" have acquired multiple meanings over the millennia. Further, I also suppose it is known that Christians considered their religion to embody "the truth."

As a matter of logic (I have in mind the richest logic currently known, namely the classical propositional and predicate calculus), "truth" and "falsity" come as a pair: each is the negation of the other. From its earliest days, Christian theology has made the distinction between true and false religions - a distinction that Islam and Judaism also make (Assmann 2010). When Christianity made the distinction between the religious and the secular, we need to realize that it was not a binary but a triad instead: true religion, false religions, and the secular; or, the religious, the idolatrous (or the profane), and the secular (Markus 2006).

The predicates "truth" and "falsity" were applied to specific actions: true religion was the act of worshipping the true God, while false religions worshipped false gods. In this sense, any act of worshipping God was true religion; any and every act of Devil's worship was false religion. The secular or religiously indifferent emerged as the leftovers: actions that belonged neither to true religion nor to false religion. That is, historically speaking, the notion of the secular emerged only after the distinction between the true and the false was made. It was also the case that some action (say, women wearing trousers, eating alone, participating in New Year celebrations of pagans, being a spectator at games, etc.) was allowed into the domain of the secular, if and only if it was deemed neither to belong to the domain of the true religion nor to the domain of the idolatrous or the profane (Markus 1990).

Let me give a few illustrations of how this triad operated in different situations in the history of Christianity. Among the early Christians, the question as to which practices they could share in common with pagans living in the Roman Empire became very important. Which of all the practices in pagan society were idolatrous or implicated in false religion? The Latin church father Tertullian addressed this issue in his De Idololatria (ca. 160-220 C.E.), where he examined a series of practices and professions to determine which of these involved idolatry (see Waszink and van Winden 1987). It is only after answering this question that clerical authorities could decide which practices were secular or indifferent to religion. In his De Spectaculis (197-202 C.E.), Tertullian 
argued that enjoying the pleasures of public shows was "inconsistent with true religion and true obedience to the true God" (Tertullian 1989:80). Christians could not participate here, but were free to engage in those practices that had been placed in the neutral secular sphere: public and private ceremonies related to betrothals, weddings, and name-giving ceremonies, the wearing of white togas, etc. In this way, the triad of true religion, false religion, and the secular drew the boundary between the Christian religious community and its pagan surroundings (De Roover 2011). This also shows that the distinction between the secular and the religious is not a "modern" one, no matter where one locates "modernity."

In colonial India, missionaries from different Christian denominations called upon the same triad in order to decide how they and their converts should relate to traditional practices of Indian society. Early modern Jesuits were in the habit of allowing new converts to retain certain local customs. However, critics not only accused them of permitting neophytes to carry on practices that were obviously idolatrous, but also charged the Jesuits with complicity in idolatry. In this "Malabar Rites" controversy, the above-mentioned triad came into effect. The papacy had to determine the status of these customs: Did they indeed belong to the realm of false religion and were they therefore incompatible with true religion? Or were these customs merely secular civil observances (Brucker 1910; Neill 2002:75-79)? Later Roman Catholic and Protestant missionaries raised similar questions about caste practices. It was crucial for them to determine whether the caste system was an institution embodying false religion and idolatry or only a secular civil institution, because this was a precondition for deciding which stance Christian believers were to take towards caste-related practices (Ballhatchet 1998; Dirks 2001; Forrester 1980; Sweetman 2007).

Because of the internal divisions within Western Christendom after the Protestant Reformation, the debates about the divide between true religion and idolatry intensified. As a consequence, the question of what was secular and what not cropped up again and again. In the eyes of the Protestant Reformers, the Roman Catholic Church itself was idolatrous: it was a human creation that pretended to be the "true" Christian Church or, in other words, a secular institution that falsely claimed to be religious in nature (Eire 1986). The clergy or priesthood was not a religious distinction, Luther argued in his Against the Spiritual Estate (1522) and elsewhere, but merely the designation of a "secular" office (Pelikan and Lehmann 1955-1986, 37:367-368, 39:287). 
Both before and after this major split in Christianity, the issue of idolatry remained important: it was prominent in the early days of Christianity; it became central once again during the iconoclastic controversy; it came to the forefront during the Reformation, and so on. That does not mean that it disappeared during the intervening periods. There was a continuous discussion of idolatry in Christianity: money was the mammon (the personification of wealth portrayed as a false god is the mammon in the Bible), usury was idolatry and hence forbidden, and greed always remained one of the cardinal sins (see the essays in Barton 2007). The sphere of the secular was constantly filtered by the notion of idolatry and only what was not idolatrous could be practiced by the Christian believers in their daily lives, precisely because it was considered secular or indifferent to religion. The secular, in this sense, had a "dark side," namely idolatry and worship of the Devil. "False" religions were always a threat to the practice of "true" religion. In the history of Christianity, the notion of the secular always required (and continues to require) the presence of the opposition between "true" and "false" religions.

\section{To Whom is the Distinction a Problem?}

To Christian believers, there is no conceptual problem involved in making the religious-secular distinction, because their theology helps them specify what true and false religion are and, as a consequence, what the secular is. If that theology tells them that saluting the flag or kissing it is not to worship either the flag or the nation but merely to "render unto Caesar what is Caesar's," then

they would not accept a description that attempts to portray the act as a religious act (for such a description, see Fitzgerald 2007b:3). The reason is not far to seek: the mere possibility of describing, say, nationalism or patriotism as "religious" acts does not make such acts religious any more than the possibility of describing human beings as "children of God" makes us effectively into children of God (Hayes 1926; Juergensmeyer 1993:16).

There can be true and false descriptions of any object, event, or situation and the mere existence of a description or the possibility of providing such a description does not guarantee that the description is also true. One can describe an act or an object in multiple ways: just because one can speak of "faith in the market," this possibility (on its own) does not make the market into a religious entity. For that to happen, in the case of the believer, one needs a theological framework that says that human beings are worshipping false gods, namely money and the market. This is completely analogous to the theological characterization of image worship: in this case too, humans 
worship their own creations. Both faith in the image and faith in the market occupy the same status according to the theological framework: they are idolatrous.

Since the theology of the Christian believer enables him to distinguish between true and false religion, it also helps him in identifying the secular as something that does not belong to the domain of the religious, whether false or true. In other words, the believer operates with a triad: the religious, the idolatrous, and the secular. If one so chooses, he or she could simply say that the secular is anything that is not religious, with the proviso that the "religious" contains both true and false religion.

At the other end of the spectrum, consistent atheists would not face a problem either: to them, all religions are embodiments of false beliefs. The word "religion," in this case, is merely another name for "ideology" (which might mean something like "false consciousness" to the atheist). Thus they efface the distinction between the religious and the secular. They may or may not consider nationalism as an ideology. "Faith" in the market can either be a belief in the truth of the statement that the market is the most efficient allocator of economic resources or that statement itself could be false and the belief in its truth would be an expression of an ideology. (After all, that is what "faith" is to them: belief in the truth.) According to the consistent atheist, any attempt to describe money and market as religious phenomena would provide us with a false description of reality, which is ideological in nature. He or she might face the problem of defining what "ideology" is or building a theory of ideology but does not face the problem of defining the "religious" and the "secular." Everything that exists, the consistent atheist might say, is secular. By saying this, he or she would also have solved the problem of giving a definition of the "secular." Of course, by saying that religion is an ideology, such an atheist is not committed to denying its efficacy in the world: in so far as people's actions are directed by such an ideology, religion (and the institutions that emerge from it) have real and tangible effects in the world.

Thus, there are two groups of people to whom the religious-secular distinction is not a problem: to one, it is not a binary but a triad; to the other, there is only the "secular." The former group adds a third element to the binary and the latter reduces it to a monad. In either case, the distinction does not pose any problems. In short: the religious-secular distinction appears to be a problem only to those who insist that it concerns a binary distinction. In this sense, one conclusion is clear: the problem is not one of distinguishing between the "religious" and the "secular," but one of insisting that this is a binary distinction. Put more generally, the distinction between the 
"religious" and the "secular" poses problems only in some particular contexts. One such context is that of religious studies, where many scholars insist that the distinction is a binary. This is something that needs to be explained and understood: Why do these scholars insist that the distinction is a binary? If it is, what exactly is the problem? Does the problem come into existence only because these scholars insist that the distinction is a binary?

There is also another fact we need to notice of when we take into consideration the two groups of people to whom the distinction is not a problem. The distinction between the religious and the secular is not purely a matter of linguistics alone. It is made within a theory about religion and, consequently, it is a theoretical distinction. To the believer, his theology makes this distinction; to the consistent atheist his theory of ideology makes the distinction. Thus, the problems that arise in distinguishing between the secular and the religious are not conceptual problems endemic to the distinction itself.

If one argues that there are no "essential" and "universal" meanings to words like "religious" and "secular," one can only suggest that their meanings are context-dependent. If the meanings of words are dependent on the context, the distinction between the meanings of these words also depends on the context. In that case too, one can only formulate the following conditional claim: in certain contexts, the binary distinction between the "religious" and the "secular" creates problems. Hence, I will address myself to the following question: What are the problems involved in making the distinction between the religious and the secular in some contexts and what are its consequences? Let me first speak about our social-political context, namely the context of liberal democracy, and then move on to touch very briefly upon our cognitive context, namely that of contemporary religious studies.

\section{Liberal Democracy and False Religion}

In a country like, say, the United States or Britain, multiple Christian groups live together. Each of these groups identifies different things as secular and different things as religious. To a Protestant, the Roman Catholic Church is a civil institution that presents itself "falsely" as a religious one; to a Catholic, just the opposite is the case. To atheists, religion itself is a human product that should be treated on par with other human products, like the IMF or trade unions or with products like art and philosophy. To believers, by contrast, religion is God's gift to humanity. 
In the absence of a universally accepted scientific theory about religion, there is only one route open to the state if it is not to favor one interpretation of religion above the others: it has to accept that multiple phenomena are called "religions" by its citizens. In the process of accepting this fact, the state has to take notice of the fact that some religions not only make the distinction between the domain of religion and those things that do not belong to this domain, but also that this distinction is actually a triad.

Historically speaking, the Western liberal democracies began by accepting the truth of the Protestant theological circumscription of religion, which all three Semitic religions also subscribe to: religion is the act of worshipping God (De Roover and Balagangadhara 2008). Because the state cannot define what God is or what it means to worship this entity and yet hope to remain religiously neutral and impartial, it was compelled to transform truth-functional statements ("religion is an act of worshipping God"; "God is such and such an entity") into claims about beliefs: "Some citizens believe that religion is the act of worshipping God." However the problem with this intentional statement is the following: if laws are promulgated which enjoin all the citizens to respect such beliefs held by their fellow-citizens, then the laws are not merely about what some citizens believe in ("some citizens believe that ...") but also regarding what their beliefs are about. That is to say, all are enjoined to "respect" some actions of their fellow-citizens because the latter believe that such acts worship God. The state has to say that some acts (according to some citizens) are acts of worship and that these acts (according to the same citizens) are directed towards an entity called "God."

There are two distinct conceptual steps involved in promulgating laws that oblige all citizens to respect such "acts of worship." A very broad historical sketch, lacking all nuances, will help to clarify both these conceptual steps. When warring Christian groups clashed with each other in the interstices of civil society, Western European and American states confronted the following problem: How to reconcile these groups, each of whom believed that their religion was the truth and others were false? Political thinkers like John Locke formulated pleas for religious toleration not only against the backdrop of such strife in civil society, but also using a cognitive background of generic protestant theology (De Roover and Balagangadhara 2009; Dunn 1969; Stanton 2006; Waldron 2002). Their pleas drew a demarcating line between the "secular" and the "religious" by calling upon such a generic theology, which made clear that the "civil magistrate" could not 
intervene in matters of religion (Locke 2003 [1689]). The liberal state that we know today is built on these foundations.

Here, the state had to settle the issue of truth: Which of all the competing religions were true? Because the state had to be tolerant with respect to all competing claims about religious truth, it took a neutral stance with respect to particular truth claims. That is, while the state confessed to its inability to determine the truth in matters of religion, it nevertheless accepted that religions were candidates for truth. This belief that religions can be true or false is presupposed by the liberal secular state (Balagangadhara and De Roover 2007).

Thus, in the first conceptual step, the state acknowledges that the question of "truth" in religious matters involves applying truth predicates to actions and entities. If that is the case, then it follows that some actions are true acts of worship, while others are false acts of worship. However, the state is not a source of theological authority and it cannot legislate what constitutes acts of worship, whether true or false. So, it transforms discussions regarding beliefs about truth into discussions about the truth of beliefs through a series of remarkable moves, which constitute the second conceptual step.

Having endorsed the belief that religion is an act of worship and that each religion is a candidate for truth, the state assumes an agnostic position with respect to truth. It refuses to say what makes some act into an act of worship by pleading inability to determine the truth in matters of religion. However, in so doing, the problem is only half-solved. The state might not be able to say what constitutes a "true" act of worship but what about "false" acts of worship? With respect to answering this question, agnosticism is not an option. Why?

One cannot be agnostic towards falsity the way one is agnostic towards truth, because truth and falsity are asymmetrical in logic: while the truth of some statements may not be able to be determined, their falsity can be recognized. The truth of a singular statement, when derived from universal premises, does not tell us that its premises are true. Only if it is known that the universal statements are true and use valid rules of inference (depending on the kind of logic used), can it then confidently be claimed that truth is transmitted from the premises to the conclusion. However, in falsity, the transmission goes the other way round: while one can derive true statements from false premises, a false conclusion transmits falsity to its premises. If the conclusion is false, at least one of the premises is necessarily false. Through false singular statements, we can have gnosis of falsity of universal statements. 
Consequently, there is only one way for the state to plead agnosticism in this case: define falsity in terms of truth. Thus the "false" is defined as that which is "not true." However, the truth in religious matters has already been defined in terms of the truth of beliefs held by some groups. Thus, the state plays the agnostic with respect to "false" religion by defining it as possibly "true" for some citizens in the polity. That is, that some acts are "not true" according to some people in its polity does not foreclose the possibility that the very same acts could be considered as "true" by other citizens at a later time. Thus, the state transforms claims about "false" acts of worship into possible claims about their "truth." In this way, it continues to be agnostic.

Now, the state can remain silent about the domain of the idolatrous or falsely religious, because the idolatry of one (say, the Roman Catholic Church according to the Protestants) is the true religion of the other (say, the Roman Catholic Church according to its self-description). In generalizing this claim across the domain of religion, the state bans all talk about "false" religions or the "idolatrous" from its vocabulary. It banishes the notion of false religion itself on the basis that some others could see the same as true religion.

If one banishes the notion of "false religion" from the domain of the "religious," where do the banished go? There is only place they can go to: the realm of the "secular." However, they are not explicitly admitted into the domain of the secular as the "purely" secular; they enter the secular domain under a false identity and, therefore, with false papers. Because the state bans all talk about falsity of religions, the false and the idolatrous too get registered as "potentially" religious in the secular domain. Not only are they "illegal" by virtue of possessing false papers but they are also alien: they become "illegal aliens" with a permanent residence in the secular domain because they have a transit visa. Thus, the idolatrous becomes the dark side not only of the secular, but also of the very distinction between the religious and the secular. Because the state does not talk about the false religion, it admits the potentially religious into the domain of the secular. That is to say, the religious enters the secular domain even if it is clothed as the possibly (or only potentially) religious.

In this way, the state creates the novel and modern domain of the "secular" that is both continuous with and breaks from the earlier domain of the secular but one which exhibits two properties: (a) In so far as the secular is formally or conceptually distinct from the religious, the religious and the secular appear as a binary opposition. But, this is merely the surface appearance. (b) Then there is the nature or structure of the secular domain, which contains two sets of actions: 
actions that consensually do not belong to the domain of the religious and those actions which could potentially migrate to the religious domain. If the secular is viewed from this perspective, then there is actually a triad even here: the actually religious, the "potential" acts that could be religious, and the truly secular. The formal or conceptual nature of this distinction (between the "religious" and the "secular") masks its triadic structure: instead of three sets of actions, there appears to be only two sets, viz., the religious and the secular.

However, if this development is closely examined, we see things differently. Any triadic relationship (say between $\mathrm{A}, \mathrm{B}$, and $\mathrm{C}$ ) can be broken down into three dyadic (or binary) relationships (A-B, B-C, and A-C). That happens in this case a well: there are the relationships between (a) the "truly" religious acts and actions indifferent to religion; (b) actions indifferent to religion and "potentially" religious acts; and (c) "truly" religious acts and "potentially" religious acts. Note that these relationships come into existence because of the demand that religions are candidates for truth and, therefore, one has to talk about falsity. Consequently, when one talks about the binary relationship between the "religious" and the "secular" domains, one fails to recognize that what exists is not a single binary relationship but three such. And these three dyadic relationships signify that the liberal state endorses a triadic relationship in the form of three binary relationships.

Consequently, we can now see how the modern secular domain is both continuous with the earlier notion of the secular and how it breaks with it. Insofar as the state endorses the triadic relationship between the religious and the secular, it remains continuous with the earlier distinction. And yet, it breaks from the old, insofar as it allows the "religious" to enter the domain of the "secular" by allowing for acts with uncertain truth-value to reside in the domain of the secular. Instead of true religion, false religions, and the secular, the modern state creates the triad of the religious, the potentially religious, and the secular.

The state legislates on issues that do not belong to the religious domain. That means acts that are "potentially" religious are included in its legislations. When do such acts migrate to the "truly" religious domain? The migration occurs if and only when the citizens challenge the scope of the secular law. As long as this does not happen, these acts have uncertain identity or truthvalue: they could also be "religious." If I may be permitted to use a religious metaphor here, the situation can be described as follows: there is the "heaven" (the "truly" religious), the "secular" (the "truly" secular), and the "purgatory" (acts that could go to heaven). In that case, we see that 
the secular itself plays a metaphorical "religious" function: the modern secular domain becomes the purgatory. But, it is purgatory without hell: some actions reside in the domain of the secular until they are granted entry into the domain of the religious. They are not "permanent" residents but only in transit. It is thus that the two aspects of the "secular" become apparent: on the one hand, it is formally distinct from the religious; on the other, because of its composition or structure it houses the "potentially" religious as well. In other words, despite the distinction between the religious and the secular, the modern domain of the secular is both "religious" and "secular."

Three further consequences are of importance here. The first is that the "religious" itself appears to lose form and shape because the "false" had provided the context in which the "true" took shape. After all, some act of worship was "true" religion, because it differentiated itself from acts of false worship. The "true" God emerges through the rejection of "false" gods (Assmann 2008, 2010). However, if one does not speak about "false" gods, who is the "true" God or what does it even mean to speak of the "true" God?

This leads to the second consequence. The early "secular" took form and shape as that domain which contained actions that were neither religious nor idolatrous. The implicit banishment of the idolatrous to the secular domain makes the modern secular become bloated and deformed: it now contains actions that could belong to the domain of religion and those that belong to the domain of the secular. Or, an implicit opposition emerges between the "religious" and the "secular" within the domain of the secular itself. Because not all secular actions (say, riding a bicycle or going to the hairdresser) are "potentially" religious acts, the religious triad is replicated and reproduced within the modern secular domain as three dyadic relationships: the secular and the "potentially" religious; the secular and the religious; and the religious and the "potentially religious."

The third consequence has to do with contestations. Because the modern domain of the secular contains "potentially" religious acts, any segment of the population can challenge the scope of the legislation and demand that some set of actions that appear to fall within the domain of the secular is actually religious. This contestation does not tell us that the distinction between the religious and the secular is a matter of power or ideology (or some mysterious expression of "power/knowledge" relationship) but that these sets of actions have uncertain truth-values.

The alleged tension between the secular and the religious, I suggest, is really between the "potentially religious" in the modern secular domain and the "religious." The "true" resides exclusively in the domain of the religious, but the "potential act" is an illegal alien with "citizenship 
rights" in the domain of the secular. Thus the real opposition is not between the two domains, the religious and the secular, but only between a part of the secular domain (the "potentially" religious) and the domain of the religious.

Let me sum up. The state leaves the sphere of religion intact because it is agnostic with respect to matters of truth. However, because it is not possible for the state to be agnostic towards falsity, it creates an opposition between the religious and the secular within the domain of the secular itself. As I have said, this does not take the form of a single binary but, instead, consists of three dyadic relationships.

\section{The Possibility of Religious Freedom}

Am I making the tired, old claim that the liberal secular state is inconsistent? No, I am not; I am saying the opposite: the liberal state is entirely consistent with respect to the moves it makes. Because the religious and the secular is a triadic relationship, a set of complex dyadic relationships comes into existence. To appreciate its consistency, consider what the state does when it confronts the opposition between the secular and the religious within the domain of the secular.

Let me take the example that Winnifred Fallers Sullivan sketches in her magnificent work The Impossibility of Religious Freedom (2007). In this case, a U.S. legal court called on religion experts to come to a judgment on the question whether the municipal cemetery regulations of the city of Boca Raton, Florida constituted a substantial burden on free exercise. The plaintiffs were people who had decorated the graves of their loved ones with a variety of vertical markers, which were not allowed by the municipal cemetery regulations. In defense, these people argued that these decorations were expressions of religion and that the regulations, which allowed only simple horizontal markers, violated their religious freedom. During the proceedings, religion experts were asked to take the stand and declare to the court whether some or another decoration to a grave was actually religious or not. In so far as these "experts" claimed that the practices of the people in question were not actually religious (even though every involved individual claimed their practices to be a part of their faith), the court ruled against the relatives of the deceased and upheld the secular law that defined how graves had to be kept. Sullivan makes a prima facie persuasive case that the "lived religion" of people from different denominations and faiths can never be accommodated within the confines of secular law and, therefore, religious freedom is impossible. Yet, there is 
another dimension that I want to focus upon: something more is at stake here than the opposition between "lived religion" and "religion."

Consider, in terms of my thesis so far, what the real contention in the court was: Did the believers who decorated the graves of their loved ones act in a religious way or were their acts not religious? Of course, all these people believed that they were religious (because they also believed that theirs is the "true" religion) and, therefore, their acts of decorating the graves were also truly religious acts. However, truth is never a matter of "lived experience." After all, a hallucination is also "lived experience" as are perceptual illusions. By virtue of this alone, they do not become true, do they?

The court had to make a judgment about the "religious" nature of the acts of some of the citizens. The state, thus, could not ask whether these acts of decorating the graves were idolatrous; it could only ask whether they were "truly" (or actually) religious. As shown, the liberal state and its courts attempt to take an agnostic stance towards "falsity" by transforming claims about falsity into claims about beliefs regarding truth. Therefore, the court has to take recourse to the pronouncements about truth (if it has to remain consistent) to determine whether the actions of these citizens were religious. But which "others" should it turn to? Consistent with the practice of embracing Semitic "theologies" to solve "religious" problems, the state and its courts do the same here as well: the courts accept the testimonies of authorities. Here too, it is important to note that the court does not "define" who an authority is, but merely accepts the claim that religious authorities determine the "truth" in religious matters.

In order to explain what the notion of religious authority signifies, suppose one asks, "Who speaks for Christianity — the king, the pope, the pious, or the book?" This question makes sense not because of any linguistic fiat, but because of the history of Christianity itself. The nature of authority is one of its most profound religious concerns: the issue is not merely about the nature of religious authority, but also regarding the relation between religious and secular authorities. There is no need to go into the details regarding either the diversity of the answers or the varied routes followed to arrive at them. We need to remember that, using the present tense for the sake of simplicity, getting the answer right is not a mere theological nicety. If one gets it wrong, one does not merely damn one's own soul, but those of the credulous as well. In so far as one is a believer, this double damnation is not of passing concern, but invites an unremitting, existential soul searching. This is not a problem for the theologian alone, but the basic quest of the believer himself. 
Within the ambit of Christianity, the "who speaks for" question is not only intelligible, it is also pregnant, poignant, and deeply ethical at the same time. "Who speaks for Christianity?" has not been asked in the course of its history as an extraneous issue. It is deeply and fundamentally constitutive of the very identity of Christianity. It is this history that compels the court to listen to "authorities" with respect to the "truth" of the acts of worship.

In short, the liberal state, in trying to transform questions about falsity into issues about "truth for others" is entirely consistent in allowing these others ("religious authorities") to tell its courts of law what that "truth" is. We cannot convict the state of inconsistency, but only argue that it accepts the "theologies" of Semitic religions.

One might be tempted to ask why the courts or the liberal state in general cannot simply accommodate the "lived religion" of the citizens, but seek to determine "truth" in religious matters instead. The reason must be obvious: the peaceful coexistence of multiple Semitic religions within the interstices of the modern Western world is possible precisely because the liberal state accepts the candidacy of religions for the status of truth, but then assumes an agnostic attitude towards the same. The kind of religious freedom that the liberal state allows is possible only because of this assumption.

\section{From Triad to Dyad}

What I have said so far is also applicable to our cognitive context, namely, the domain of religious studies. Scholars here assume (in most cases) an agnostic stance with respect to truth or fail in being consistently atheistic. The problem they then confront is of their own making: they accept Christian theology in an inconsistent way, attempt to reduce a triad to a single binary and thus face all the problems of the "idolatrous" parading as denizens of the realm of the secular. In contradistinction to the liberal state, which breaks the triad down into three dyads, the intellectuals attempt to reduce a triad into a single binary, which creates all kinds of problems.

The issue is not that of a dichotomous relationship between the "religious" and the "secular," but rather that of the relationships between the "religious," the "potentially religious" and the "secular." This is also the reason why, in challenging the distinction between the secular and the religious, scholars like Timothy Fitzgerald appeal to phenomena that the Semitic religions have already described as idolatry: the market, money, nationalism, sports, plays, etc. One reproduces old theological descriptions of these practices but believes that one is thereby providing 
a "religious" description of "secular" phenomena. All that one is signaling here is that the realm of the secular today includes practices that were once considered as expressions of false religions but live on in the secular today as possibly religious acts.

In other words, I do not believe that there is any kind of problem about the existence of a binary distinction between the "religious" and the "secular." Even though the complex relationships between the religious and the secular are important, the distinction as such has no interesting implications for the study of human society. However, there is the phenomenon of the failed reduction of a triad to a single dyad, which has generated the issues that some of the intellectuals in the Western world face today.

\section{References}

Agrama, Hussein Ali. 2010. "Secularism, Sovereignty, Indeterminacy: Is Egypt a Secular or a Religious State?" Comparative Studies in Society and History 52(3):495-523.

Asad, Talal. 2003. Formations of the Secular: Christianity, Islam, Modernity. Stanford: Stanford University Press.

Assmann, Jan. 2008. Of God and Gods: Egypt, Israel, and the Rise of Monotheism. Madison: University of Wisconsin Press.

2010. The Price of Monotheism. Stanford, Calif.: Stanford University Press.

Balagangadhara, S. N. and Jakob De Roover. 2007. "The Secular State and Religious Conflict: Liberal Neutrality and the Indian Case of Pluralism." The Journal of Political Philosophy 15(1):67-92.

Ballhatchet, Kenneth. 1998. Caste, Class and Catholicism in India 1789-1914. London: Curzon.

Barton, Stephen, ed. 2007. Idolatry: False Worship in the Bible, Early Judaism and Christianity. London and New York: T\&T Clark.

Berger, Alan, ed. 2011. Saul Kripke. Cambridge: Cambridge University Press.

Besserman, Lawrence. 2006. "Introduction: Sacred and Secular in Medieval and Early Modern Cultures: Issues and Approaches.” In Lawrence Besserman (ed.), Sacred and Secular in Medieval and Early Modern Cultures: New Essays, New York: Palgrave Macmillan, 1-18.

Brucker, Joseph. 1910. "Malabar Rites.” In Charles G. Herbermann (ed.), The Catholic Encyclopedia, vol. 9, New York: Robert Appleton Company, 558-562.

Casanova, José. 2006. "Secularization Revisited: A Reply to Talal Asad.” In David Scott and Charles Hirschkind (eds.), Powers of the Secular Modern: Talal Asad and His Interlocutors, Stanford: Stanford University Press, 1230.

Cavanaugh, William T. 2009. The Myth of Religious Violence. Oxford: Oxford University Press.

De Roover, Jakob. 2011. "Secular Law and the Realm of False Religion.” In Winnifred Fallers Sullivan, Robert Yelle, and Mateo Taussig-Rubbo (eds.), After Secular Law, Stanford: Stanford University Press, 43-61. 
De Roover, Jakob and S. N. Balagangadhara. 2008. "John Locke, Christian Liberty and the Predicament of Liberal Toleration." Political Theory: An International Journal of Political Philosophy 36(4):523-549.

- 2009. "Liberty, Tyranny and the Will of God: The Principle of Toleration in Early Modern Europe and Colonial India." History of Political Thought 30(1):111-139.

Dirks, Nicholas B. 2001. Castes of Mind: Colonialism and the Making of Modern India. Princeton, N.J.: Princeton University Press.

Dunn, John. 1969. The Political Thought of John Locke: An Historical Account of the Argument of the "Two Treatises of Government." Cambridge: Cambridge University Press.

Eire, Carlos. 1986. War Against the Idols: The Reformation of Worship from Erasmus to Calvin. Cambridge: Cambridge University Press.

Fitzgerald, Timothy. 2007a. Discourse on Civility and Barbarity: A Critical History of Religion and Related Categories. Oxford: Oxford University Press.

- 2007b. "Introduction." In Timothy Fitzgerald (ed.), Religion and the Secular: Historical and Colonial Formations, London: Equinox, 1-25.

—. 2007c. "Encompassing Religion, Privatized Religions and the Invention of Modern Politics." In Timothy Fitzgerald (ed.), Religion and the Secular: Historical and Colonial Formations, London: Equinox, 211-241.

Forrester, Duncan B. 1980. Caste and Christianity: Attitudes and Policies on Caste of Anglo-Saxon Missions in India. London: Curzon.

Hayes, Carlton J. H. 1926. Essays on Nationalism. New York: Macmillan.

Juergensmeyer, Mark. 1993. The New Cold War? Religious Nationalism Confronts the Secular State. Berkeley, Calif.: University of California Press.

Kripke, Saul. 1981. Naming and Necessity. London: Wiley-Blackwell.

Lewis, David. 2001. On the Plurality of Worlds. London: Wiley-Blackwell.

Locke, John. 2003 [1689]. “A Letter Concerning Toleration.” In Ian Shapiro (ed.), Two Treatises of Government and a Letter Concerning Toleration, New Haven and London: Yale University Press.

Markus, Robert A. 1990. The End of Ancient Christianity. Cambridge: Cambridge University Press.

- 2006. Christianity and the Secular. Notre Dame, Ind.: University of Notre Dame Press.

Neill, Stephen. 2002. A History of Christianity in India: 1707-1858, vol. 2. Cambridge: Cambridge University Press.

Pelikan, Jaroslav and Helmut T. Lehmann, eds. 1955-1986. Luther's Works, American ed. 55 vols. Philadelphia and St. Louis: Fortress Press and Concordia Publishing House.

Stanton, Tim. 2006. "Locke and the Politics and Theology of Toleration." Political Studies 54(1):84-102.

Starrett, Gregory. 2010. “The Varieties of Secular Experience.” Comparative Studies in Society and History 52(3):626651.

Sullivan, Winnifred F. 2007. The Impossibility of Religious Freedom. Princeton: Princeton University Press.

Sweetman, Will. 2007. "Colonialism All the Way Down? Religion and the Secular in Early Modern Writing on South India." In Timothy Fitzgerald (ed.), Religion and the Secular: Historical and Colonial Formations, London: Equinox, 117-135. 
Tertullian. 1989. "The Shows or De Spectaculis.” In Rev. Alexander Roberts and Sir James Donaldson (eds.), The Ante-Nicene Fathers: The Writings of the Fathers Down to A.D. 325, vol. 3, Grand Rapids: Wm. B. Eerdmans, 79-91.

van Bremen, Jan. 1995. Ceremony and Ritual in Japan: Religious Practices in an Industrialised Society. London: Routledge.

Waldron, Jeremy. 2002. God, Locke, and Equality: Christian Foundations in Locke's Political Thought. Cambridge: Cambridge University Press.

Waszink, J. H. and J. C. M. van Winden, eds. and trans. 1987. Tertullian: De Idololatria. Leiden and New York: Brill. 